\title{
Investigation of organochlorine pesticides (OCPs) in mollusks collected from coastal sites along the Chinese Bohai Sea from 2002 to 2004
}

\author{
Yawei Wang, Ruiqiang Yang, Guibin Jiang* \\ State Key Laboratory of Environmental Chemistry and Ecotoxicology, Research Center for Eco-Environmental Sciences, \\ Chinese Academy of Sciences, P.O. Box 2871, 18 Shuangqing Road, Haidian District, Beijing 100085, China
}

Received 5 December 2005; received in revised form 1 June 2006; accepted 17 June 2006

Concentration of organochlorine pesticides in mollusks collected from coastal sites along the Chinese Bohai Sea didn't change obviously from 2002 to 2004.

\begin{abstract}
Mollusks living in seas can accumulate organochlorine pesticides (OCPs). The residue levels of selected OCPs: dichlorodiphenyltrichloroethane ( $p, p^{\prime}$-DDT, $o, p^{\prime}$-DDT, $p, p^{\prime}$-DDE, $p, p^{\prime}$-DDD), hexachlorocyclohexanes $(\alpha-, \beta-, \gamma$ - and $\delta$-HCH) in gastropod and bivalve species collected from ten coastal cites along the Chinese Bohai Sea were investigated from 2002 to 2004. The species included nine kinds of mollusks: Rapana venosa, Neverita didyma, Scapharca subcrenata, Mytilus edulis, Amusium, Crassostrea talienwhanensis, Meretix meretrix, Sinonovacula constricta, Ruditapes philippinarum, Mactra veneriformis. The results showed that OCPs widely existed in the mollusks organisms. $p, p^{\prime}$-DDT, $p, p^{\prime}$-DDE, $\beta$-HCH were the major compounds. Statistical analysis (One-way ANOVA) showed that the contents of OCPs in these mollusks did not change obviously from 2002 to 2004. Principal component analysis (PCA) was also used for determining the polluting characters existing in this selected field.
\end{abstract}

(C) 2006 Elsevier Ltd. All rights reserved.

Keywords: Mollusks; DDTs; HCHs; Principal component analysis; Bohai Sea

\section{Introduction}

Organochlorine pesticides (OCPs) are a common name of a group of pesticides consisting of benzene and chlorine, which have been of great of concern because of the large production and usage. Some OCPs belong to the Persistent Organic Pollutants (POPs) that are semi-volatile, environmental persistent, toxic. OCPs have bioaccumulation potential in organisms and long-term adverse effect on ecosystems and human health (Doong et al., 2002; Vallack et al., 1998; Jones and de Voogt, 1999). Considering to their harmful effects on

\footnotetext{
* Corresponding author. Tel.: +86106284 9334; fax: +861062849179.

E-mail address: gbjiang@rcees.ac.cn (G. Jiang).
}

human and ecosystem, during the last 30 years, many international agreements are coming into effect to reduce the environmental burden by reducing or withdrawing the registered usage of OCPs, for example, aldrin, diedrin, endrin, mirex, etc. But some of them, such as lindane (pure $\gamma-\mathrm{HCH}$ ), are still used in some countries. In China, 1,2,3,4,5,6-hexachlorocyclohexane (HCHs), and dichlorodiphenyltrichloroethane (DDTs) were extensively used as pesticides for agricultural activities. Especially during 1960s to 1983, HCHs and DDTs accounting for about $78 \%$ of total pesticide production and usage (Hua and San, 1996; Li et al., 1998). Although the concentrations of OCPs in environmental matrix and foodstuffs have decreased since the 1980 s because of the governmental restrictive measure, many studies showed the residues are still high (Nakata et al., 2002; Xu et al., 2004; Chen and Gao, 1993). 
Mollusks have been widely used to monitor the quality of water ecosystems since the late 1980s for their abundance in many terrestrial and aquatic ecosystems, being easily available for collection. They are highly tolerant to many pollutants and exhibit high accumulation property (Bervotes et al., 2005; Kim et al., 2002). Usually, the level of OCPs in organisms is relatively higher than those in the surrounding water. So, the analysis of OCPs in mollusks can help to monitor the quality of marine water and estimate the food safety risk for local people.

The Bohai Sea is a semi-enclosed coastal water body of Northwest Pacific. The coastal line of the Bohai Sea has a length of nearly $3800 \mathrm{~km}$ (Wei et al., 2002), with a surface area of $77 \times 10^{9} \mathrm{~m}^{2}$. The Yellow River, Liaohe, Haihe and Luanhe (Fig. 1) are the major fresh water sources discharging directly to the Bohai Sea. The drainage areas of these rivers are the important agricultural and chemical production area.

The Bohai Strait in the east is the only passage connecting the Bohai Sea to the outer Yellow Sea. Once polluted, it needs a long period of time for water quality to resume.

In this study, nine widely distributed mollusk species were collected from ten sites around the Bohai Sea $\left(37^{\circ} 30^{\prime}-4100^{\prime} \mathrm{N}\right.$ latitude, $11^{\circ} 30^{\prime}-121^{\prime} 30^{\prime} \mathrm{E}$ longitude). The main objectives are to investigate the residuals of HCHs and DDTs in the tissues of selected mollusks and evaluate the pollution levels of $\mathrm{HCHs}$ and DDTs in these sites.

\section{Materials and methods}

\subsection{Sampling sites and samples collection}

The sampling was carried out thrice from 2002 to 2004. The sampling period is from the end of July to the beginning of August in every year. Fig. 1 showed the map of the Bohai Sea and the sampling sites: Weihai, Yantai, Penglai, Laizhou, Yangkou, Tianjin, Huludao, Jinzhou, Yingkou, Dalian.

The species of selected mollusks (Table 1) were identified according to the catalog of marine mollusks in the reference book (Qi et al., 1989). The

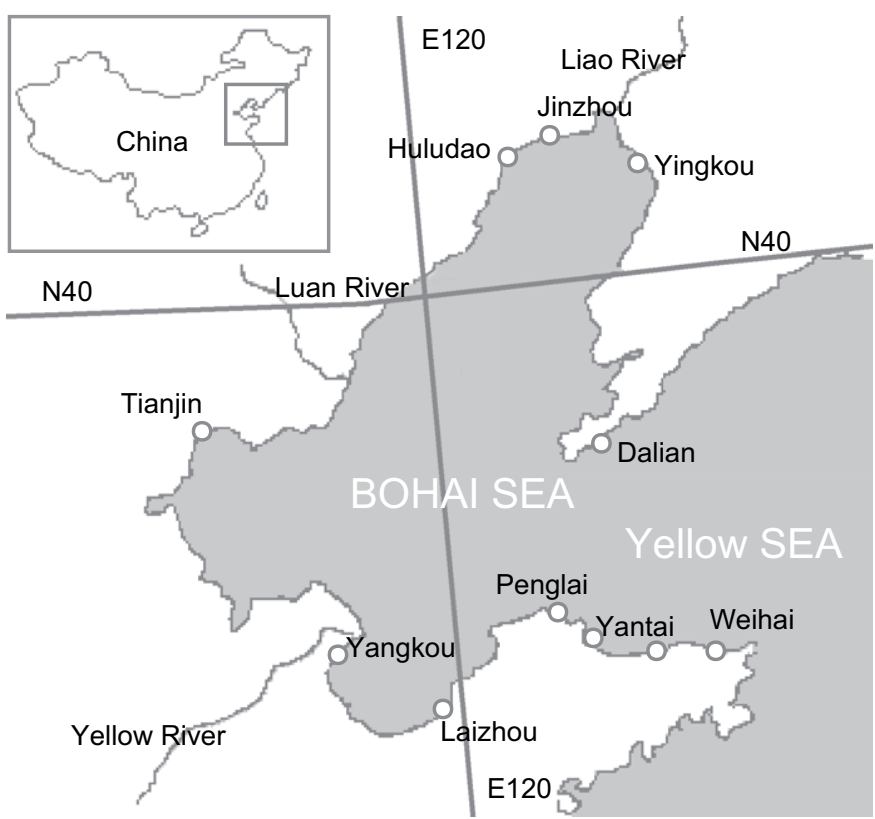

Fig. 1. Sampling locations of mollusk samples along the Chinese Bohai Sea.
Table 1

The denomination of the selected mollusks

\begin{tabular}{clll}
\hline & Species & Abbreviate & Denomination \\
\hline Gastropod & Rapana venosa & Rap & Valenciennes, \\
(Predator) & & & 1846 \\
& Neverita didyma & $\mathrm{Nev}$ & Röding, 1798 \\
Bivalve & Scapharca subcrenata & $\mathrm{Sca}$ & Lischke, 1869 \\
(Herbivore) & Mytilus edulis & $\mathrm{Myt}$ & Linnaeus, 1758 \\
& Amusium & $\mathrm{Amu}$ & Röding, 1798 \\
& Crassostrea & Cra (Ost) & Crosse, 1862 \\
& talienwhanensis & & \\
& Meretix meretrix & Mer & Linnaeus, 1758 \\
& Sinonovacula constricta & Sin & Lamarck, 1818 \\
& Ruditapes philippinarum & Rud & Adams \& Reeve, \\
& & & 1850 \\
& Mactra veneriformis & Mac & Reeve, 1854 \\
\hline
\end{tabular}

collected mollusks were depurated in filtered seawater for $24 \mathrm{~h}$ before transported to the laboratory with ice freezing. The soft tissues of mollusks were excised by stainless steel scalpel blades, and then thoroughly rinsed with Milli-Q water to remove extraneous impurities. After sufficient homogenate by a blender, the samples were kept at $-20{ }^{\circ} \mathrm{C}$ until analysis.

\subsection{Chemical analysis}

\subsubsection{Samples pretreatment}

The pretreatment was modified according to the method by the work of Tanabe et al. (2000). Approximately $10 \mathrm{~g}$ (wet weight) homogenized soft tissues were added by appropriate anhydrous sodium sulfate, and mixed well using a glass rod. A suitable amount of internal standard (PCB-209, $0.2 \mu \mathrm{g} \mathrm{mL}^{-1}$ ) was added. The mixtures then were extracted with sonication method by $80 \mathrm{~mL} \mathrm{1:1} \mathrm{(v/v)} \mathrm{hexane:} \mathrm{dichloromethane} \mathrm{for} 60 \mathrm{~min}$, then stood overnight. The extract was concentrated to about $1-2 \mathrm{~mL}$. The concentrated extract was subjected to clean up by elution through a glass column $(12 \mathrm{~mm}$ i.d.) filled with $10 \mathrm{~g}$ florisil. The analytes were eluted by $10 \mathrm{~mL} n$-hexane

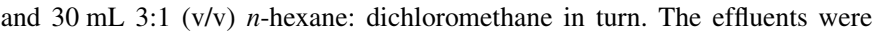
combined and the volume of samples was concentrated to about $1 \mathrm{~mL}$ by a gentle stream of nitrogen gas.

\subsubsection{Standards, regents, and instrumental}

The mixed OCPs standard solution including $\alpha-, \beta-, \gamma-, \delta$-HCH, $p, p^{\prime}$-DDT, $o, p^{\prime}$-DDT, $p, p^{\prime}$-DDE, $p, p^{\prime}$-DDD was purchased from National Research Center for Certified Reference Materials of China. The corresponding individual standards were also prepared for qualitative purpose. The internal standard 2,2' $, 3,3^{\prime}, 4,4^{\prime}, 5,5^{\prime}, 6,6^{\prime}$-decachlorobiphenyl was purchased from Accustandard, Inc. USA. All solvents were analytical-grade (Beijing Chemical Regents Factory, China).

The quantification of OCPs was performed by an Agilent 6890A gas chromatography (GC) equipped with a ${ }^{63} \mathrm{Ni}$ electron capture detector (micro-ECD) (Agilent, USA). A HP-1 fused-silica column $(50 \mathrm{~m} \times 0.25 \mathrm{~mm}$ i.d., $0.25 \mu \mathrm{m}$ film thickness) was used for separation with high purity $\mathrm{N}_{2}$ as the carrier gas and make-up gas at flow rate of $1 \mathrm{~mL} \mathrm{~min}^{-1}$ and $49 \mathrm{~mL} \mathrm{~min}^{-1}$, respectively. The GC system was operated in a splitless mode and $1 \mu \mathrm{L}$ of the extracts was injected through a programmable temperature vaporization (PTV). The oven temperature was raised from $80{ }^{\circ} \mathrm{C}$ to $200{ }^{\circ} \mathrm{C}$ at a rate of $10^{\circ} \mathrm{C} / \mathrm{min}$, hold for $1 \mathrm{~min}$, and then programmed to $270^{\circ} \mathrm{C}$ at $5{ }^{\circ} \mathrm{C} / \mathrm{min}$, hold for $5 \mathrm{~min}$. The injector and detector were maintained at $250{ }^{\circ} \mathrm{C}$ and $280{ }^{\circ} \mathrm{C}$, respectively.

The residues of $\mathrm{HCHs}$ and DDTs were quantitatively determined by the calibration curves of the standards using peak areas. The quantitative determinations were performed be internal standard procedure. The quality assurance of analytical method could be found in our previous work (Yang et al., 2004).

\subsection{Statistical analysis}

Multivariate analysis method, principal component analysis (PCA) was used to extract of information from the chemical analysis of organisms (Hobbs 
Table 2

The residue levels of $* \Sigma \mathrm{HCHs}$ (2002 to 2004) and $\mathrm{EDDTs}$ (2002 to 2004) in mollusks from sampling sites along Bohai Sea, China (ng g ${ }^{-1}$, wet weight)

\begin{tabular}{|c|c|c|c|c|c|c|c|}
\hline \multirow[t]{2}{*}{ Site } & \multirow[t]{2}{*}{ Species } & \multicolumn{3}{|c|}{$\sum \mathrm{HCHs}$} & \multicolumn{3}{|c|}{$\sum \mathrm{DDTs}$} \\
\hline & & 2002 & 2003 & 2004 & 2002 & 2003 & 2004 \\
\hline \multirow[t]{9}{*}{ Dalian } & Rap & 1.94 & 2.09 & 1.79 & 55.74 & 28.14 & 28.03 \\
\hline & $\mathrm{Nev}$ & 2.01 & 1.23 & & 20.42 & 50.71 & \\
\hline & Cra & 0.73 & 2.28 & 1.36 & 20.66 & 67.82 & 65.88 \\
\hline & Myt & 1.01 & 1.48 & 1.34 & 39.18 & 40.93 & 35.29 \\
\hline & Amu & 0.72 & 1.71 & & 12.75 & 41.41 & \\
\hline & Sin & 1.07 & 1.00 & 1.07 & 40.32 & 117.04 & 38.71 \\
\hline & Rud & 0.85 & 0.99 & 1.21 & 23.26 & 24.69 & 19.38 \\
\hline & Mac & & 1.22 & 1.00 & & 30.54 & 26.03 \\
\hline & Mer & 2.41 & & 2.16 & 21.52 & & 25.74 \\
\hline \multirow[t]{9}{*}{ Yingkou } & Rap & 3.35 & 0.73 & 2.51 & 13.37 & 19.97 & 13.26 \\
\hline & $\mathrm{Nev}$ & 1.71 & & 1.64 & 8.87 & & 22.21 \\
\hline & Myt & 0.86 & 0.94 & 1.82 & 11.28 & 15.79 & 28.07 \\
\hline & Amu & 0.86 & 0.95 & & 11.42 & 34.92 & \\
\hline & Sin & 1.28 & & 1.77 & 47.33 & & 55.56 \\
\hline & Sca & & 2.72 & 3.06 & & 19.68 & 53.72 \\
\hline & Rud & 1.02 & 1.23 & 1.70 & 45.01 & 14.66 & 7.51 \\
\hline & Mac & & 4.77 & 1.00 & & 14.22 & 6.87 \\
\hline & Mer & & 0.92 & 2.16 & & 26.84 & 10.53 \\
\hline \multirow[t]{9}{*}{ Jinzhou } & Rap & 0.80 & 1.58 & 1.04 & 14.99 & 13.56 & 7.79 \\
\hline & $\mathrm{Nev}$ & 0.32 & 1.05 & 1.39 & 50.26 & 11.58 & 9.52 \\
\hline & $\mathrm{Cra}$ & & 1.72 & 1.20 & & 27.8 & 16.36 \\
\hline & Myt & 2.27 & 1.01 & 1.12 & 13.23 & 27.37 & 10.59 \\
\hline & Sin & & 1.07 & 2.18 & & 21.48 & 26.61 \\
\hline & Sca & 1.56 & 1.04 & 1.35 & 40.97 & 11.9 & 5.49 \\
\hline & Rud & 0.68 & 1.97 & & 14.74 & 21.73 & \\
\hline & Mac & 0.1 & 1.04 & 0.96 & 33.16 & 68.43 & 23.28 \\
\hline & Mer & 0.94 & 0.86 & 1.34 & 22.57 & 20.53 & 20.53 \\
\hline \multirow[t]{8}{*}{ Huludao } & Rap & 1.88 & 2.78 & 1.37 & 17.26 & 21.37 & 13.51 \\
\hline & $\mathrm{Nev}$ & 2.96 & 1.41 & 1.52 & 14.13 & 23.16 & 20.08 \\
\hline & $\mathrm{Cra}$ & & 0.84 & 1.92 & & 47.42 & 25.47 \\
\hline & Amu & & 1.37 & 1.35 & & 25.15 & 22.63 \\
\hline & Sin & 2.34 & 0.73 & 1.60 & 44.46 & 52.51 & 96.01 \\
\hline & Sca & 2.38 & 0.71 & 1.13 & 28.56 & 12.97 & 8.58 \\
\hline & Rud & 0.75 & 1.01 & 0.89 & 62.04 & 10.58 & 3.34 \\
\hline & Mer & 1.14 & & 2.81 & 18.72 & & 21.08 \\
\hline \multirow[t]{6}{*}{ Tianjin } & Rap & 1.36 & 2.26 & 2.71 & 15.78 & 40.87 & 33.96 \\
\hline & $\mathrm{Nev}$ & 4.21 & 2.08 & 0.91 & 58.94 & 69.76 & 50.52 \\
\hline & Cra & 1.88 & 1.30 & 1.91 & 44.41 & 106.24 & 72.93 \\
\hline & Sin & 1.37 & 1.24 & 4.55 & 91.74 & 118.37 & 173.90 \\
\hline & Sca & 1.84 & 1.50 & & 15.96 & 35.38 & \\
\hline & Mer & 0.59 & 2.26 & 2.45 & 43.93 & 39.8 & 33.48 \\
\hline \multirow[t]{7}{*}{ Yangkou } & Rap & 1.49 & & 2.26 & 18.73 & & 28.15 \\
\hline & $\mathrm{Nev}$ & 0.69 & 1.33 & 0.93 & 18.00 & 11.85 & 11.89 \\
\hline & Sin & 2.17 & 1.64 & 1.13 & 41.21 & 94.49 & 19.39 \\
\hline & Sca & 2.30 & 2.09 & 1.03 & 35.29 & 23.99 & 22.87 \\
\hline & Rud & & 1.91 & 1.93 & & 27.61 & 20.37 \\
\hline & Mac & 1.31 & 1.87 & 2.28 & 16.16 & 12.59 & 20.83 \\
\hline & Mer & & 2.28 & 2.79 & & 19.23 & 21.02 \\
\hline \multirow[t]{8}{*}{ Laizhou } & Rap & 2.50 & 2.04 & 2.09 & 44.77 & 57.81 & 22.76 \\
\hline & $\mathrm{Nev}$ & 0.77 & 1.47 & 2.00 & 36.43 & 26.9 & 23.34 \\
\hline & $\mathrm{Cra}$ & 1.99 & 1.49 & 1.42 & 13.51 & 21.2 & 24.26 \\
\hline & Myt & 0.67 & 2.00 & 1.32 & 9.06 & 35.29 & 41.46 \\
\hline & Sin & 1.82 & 3.10 & 1.40 & 14.71 & 73.08 & 94.48 \\
\hline & Rud & 5.92 & 1.40 & 1.17 & 49.39 & 42.26 & 15.24 \\
\hline & Mac & 2.55 & & 0.90 & 23.48 & & 19.05 \\
\hline & Mer & 2.64 & 1.18 & 2.99 & 10.86 & 22.16 & 11.03 \\
\hline \multirow[t]{6}{*}{ Penglai } & Rap & & 2.71 & 3.96 & & 25.01 & 15.08 \\
\hline & $\mathrm{Nev}$ & 2.82 & 1.16 & 0.81 & 33.70 & 37.1 & 14.08 \\
\hline & $\mathrm{Cra}$ & 1.18 & 0.72 & 2.05 & 23.28 & 35.15 & 26.18 \\
\hline & Myt & 0.85 & 1.50 & 1.46 & 16.07 & 63.12 & 54.00 \\
\hline & Amu & 0.81 & & 1.27 & 49.10 & & 10.08 \\
\hline & Sca & 1.65 & 0.73 & 1.29 & 18.02 & 13.24 & 25.76 \\
\hline
\end{tabular}

Table 2 (continued)

\begin{tabular}{|c|c|c|c|c|c|c|c|}
\hline \multirow[t]{2}{*}{ Site } & \multirow[t]{2}{*}{ Species } & \multicolumn{3}{|c|}{$\sum \mathrm{HCHs}$} & \multicolumn{3}{|c|}{$\sum \mathrm{DDTs}$} \\
\hline & & 2002 & 2003 & 2004 & 2002 & 2003 & 2004 \\
\hline & Sin & & 1.12 & 1.91 & 53.63 & 77.43 & 177.72 \\
\hline & Rud & 0.78 & 1.40 & 1.31 & 51.33 & 41.5 & 18.79 \\
\hline & Mer & & 0.79 & 0.74 & & 25.53 & 31.72 \\
\hline \multirow[t]{9}{*}{ Yantai } & Rap & 1.59 & 1.64 & 2.14 & 57.09 & 21.85 & 6.52 \\
\hline & $\mathrm{Nev}$ & 1.33 & 1.22 & 2.34 & 42.98 & 18.79 & 11.83 \\
\hline & Cra & 3.49 & 0.76 & 1.14 & 28.20 & 36.69 & 57.72 \\
\hline & Myt & 1.35 & 2.62 & 2.09 & 27.93 & 51.03 & 47.14 \\
\hline & Amu & 1.17 & 1.01 & 1.25 & 48.30 & 12.45 & 13.57 \\
\hline & Sca & & 1.26 & 2.37 & & 20.24 & 9.21 \\
\hline & Sin & 2.15 & 4.27 & 2.21 & 151.00 & 124.61 & 48.69 \\
\hline & Rud & & 0.91 & 1.81 & & 23.4 & 15.66 \\
\hline & Mer & 3.51 & 1.55 & 3.26 & 14.54 & 21.87 & 7.88 \\
\hline \multirow[t]{10}{*}{ Weihai } & Rap & 2.29 & 1.31 & 3.03 & 40.98 & 50.06 & 31.64 \\
\hline & $\mathrm{Nev}$ & 0.83 & 1.34 & 0.94 & 23.40 & 46.31 & 34.57 \\
\hline & Cra & 1.49 & 1.67 & 0.87 & 95.98 & 68.66 & 89.53 \\
\hline & Myt & 1.72 & 1.11 & 1.74 & 89.00 & 152.97 & 45.61 \\
\hline & Amu & 1.79 & 4.32 & 1.13 & 21.6 & 47.71 & 13.31 \\
\hline & Sca & 4.38 & 1.51 & 1.17 & 45.56 & 15.28 & 27.58 \\
\hline & Sin & 2.13 & 2.49 & 0.72 & 113.5 & 72.51 & 97.55 \\
\hline & Rud & & 1.75 & 1.45 & & 18.02 & 63.87 \\
\hline & Mac & 0.90 & 4.18 & & 36.29 & 17.74 & \\
\hline & Mer & 0.74 & 1.06 & 0.77 & 21.74 & 10.91 & 28.64 \\
\hline
\end{tabular}

$* \Sigma$ HCHs and $\Sigma$ DDTs is the sum of $\alpha-, \beta-, \gamma-\delta-\mathrm{HCH}$, and $p, p^{\prime}$-DDT $o, p^{\prime}-$ DDT $p, p^{\prime}$-DDE $p, p^{\prime}$-DDD, respectively.

et al., 2003; Cleemann et al., 2000; Manz et al., 2001; Jacobs et al., 2004). In this paper, PCA was executed on the analytical data in order to obtain a visual representation of the main characteristics of relationship among these OCPs concentrations in the studied mollusks. The combined plot of scores and loadings allowed us to recognize groups of samples with similar behavior and the existing correlation among the original variables. Usually the PCs are obtained by their eigenvalues $>1$. All statistical analysis was performed with SPSS 12.0 for windows release 12.0 (4 Sep. 2003, SPSS Inc., 1989-2003).

\section{Results and discussion}

\subsection{Concentration profiles of $\mathrm{HCHs}$ and DDTs}

The results of quantitative determination of OCPs were listed in Table 2. The contents were expressed as $\mathrm{ng} \mathrm{g}^{-1}$ based on wet weight. The dominant contaminations were DDTs with the concentration of $\sum$ DDTs ranging from the $8.87 \mathrm{ng} \mathrm{g}^{-1}$ (Yingkou, Nev) to $151.00 \mathrm{ng} \mathrm{g}^{-1}$ (Yantai, Sin) for 2002, $10.58 \mathrm{ng} \mathrm{g}^{-1}$ (Huludao, Rud) to $152.97 \mathrm{ng} \mathrm{g}^{-1}$ (Weihai, Myt) for 2003, $3.34 \mathrm{ng} \mathrm{g}^{-1}$ (Huludao, Rud) to $177.72 \mathrm{ng} \mathrm{g}^{-1}$ (Penglai, Sin) for 2004, respectively. The concentrations of $\sum \mathrm{HCHs}$ range from the $0.1 \mathrm{ng} \mathrm{g}^{-1}$ (Jinzhou, Mac) to $5.92 \mathrm{ng} \mathrm{g}^{-1}$ (Laizhou, Rud) for 2002, $0.71 \mathrm{ng} \mathrm{g}^{-1}$ (Huludao, Sca) to $4.77 \mathrm{ng} \mathrm{g}^{-1}$ (Yingkou, Mac) for 2003, $0.72 \mathrm{ng} \mathrm{g}^{-1}$ (Weihai, Sin) to $4.55 \mathrm{ng} \mathrm{g}^{-1}$ (Tianjin, Sin) for 2004, respectively.

Statistical analysis of the trends for OCPs of the thrice sampling in mollusks is presented as box-and whisker plots (Fig. 2a,b). In this layout, the boxes enclose the middle half of the data. The horizontal line in the box represents the median, the low and upper edge of the box mark the 25th and 75th percentiles. The whiskers extending from the box represent the highest and lowest values, excluding outliers. Singular 

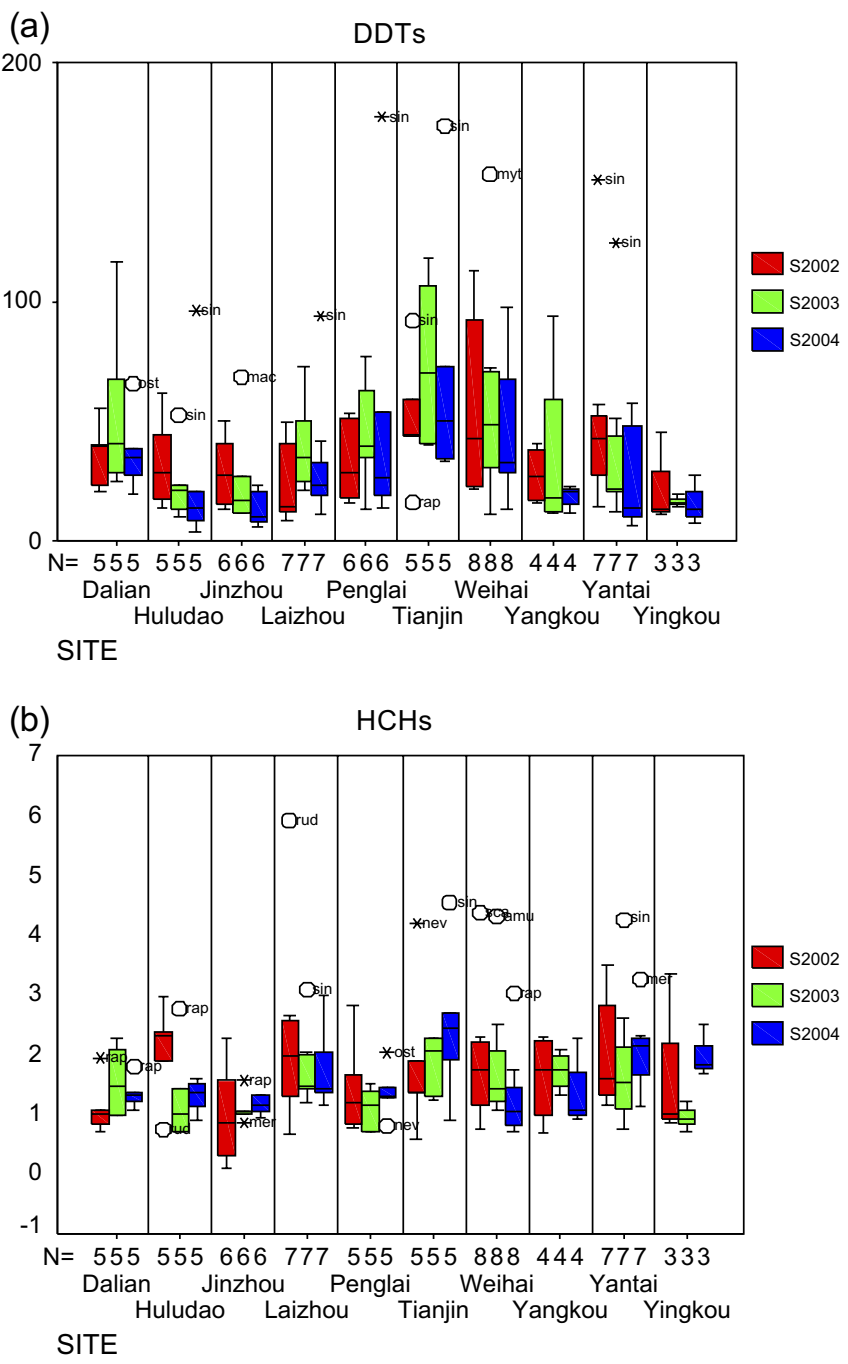

Fig. 2. Box-and-whisker plots for $\Sigma$ OCPs of the thrice sampling in mollusks. From left to right of every group, in turn, three boxes represent content of DDTs (a); and HCHs (b) in mollusks collected in 2002, 2003, and 2004, respectively.

values are represented by "O", which beyond the 150 percentiles of the difference between 25th and 75th percentiles. Extremum values are represented by "**", which beyond the triplication of the difference between 25th and 75th percentiles.

In Table 2 and Fig. 2 we could find that at a whole, there are no significant differences for $\sum \mathrm{HCHs}$ in mollusks at ten different sampling sites. For $\sum D D T s$, the residual levels in mollusks of Dalian, Tianjin, and Weihai are relative high. For other sampling sites, the polluted levels are comparative. In addition, the residuals of $\sum \mathrm{HCHs}$ and $\sum$ DDTs in bivalve mollusk Sin are relative higher than those in other many sampling sites, which exhibited its high abilities of bioaccumulation for OCPs relative to other selected mollusks.

Further, One-way ANOVA was used to setup the database of $\sum$ HCHs and $\sum$ DDTs and the results were shown in Table 3. A value of $p<0.05$ was considered to indicate a significant difference in all statistical analysis. The results showed that
Table 3

One-Way ANOVA for the concentrations of OCPs in mollusks in three years

\begin{tabular}{llll}
\hline & $P$ & & \\
\cline { 2 - 4 } & 2002 vs & 2003 vs & 2002 vs \\
& 2003 & 2004 & 2004 \\
\hline$\sum$ HCH & 0.461 & 0.529 & 0.065 \\
$\sum$ DDTs & 0.523 & 0.755 & 0.451 \\
\hline
\end{tabular}

the polluted levels in this area are not significant change in the period of three years.

OCPs in mollusks have been reported for various regions around the world. The concentrations varied substantially within the sampling locations (Table 4). The concentrations of DDTs reached $121 \mathrm{ng} \mathrm{g}^{-1}$ in a number of Oyster samples in Taiwan (Ling and Teng, 1997). Comparing to other area, OCPs contamination in mollusks living in Bohai Sea are not so high. The HCHs in mollusks living in Bohai Sea are at relative low levels.

\subsection{The results of principal component analysis}

\subsubsection{The results of $\mathrm{HCHs}$}

PCA was performed to analyze the residual of $\mathrm{HCHs}$ of the three batches of data (Fig. 3a-c). Fig. 3a represents the first sampling (2002) of loading and scores plots. PC1 of Fig. 3a accounted for $63.10 \%$ of the total variance and PC2 accounted for $22.95 \%$. In the plot of Fig. 3a, we could see that Laizhou was relatively higher contaminated by $\beta-\mathrm{HCH}$ and $\gamma-\mathrm{HCH}$. The pollution of $\Sigma \mathrm{HCH}$ in Jinzhou and Dalian were not so serious against to other selected sampling sites. Fig. $3 b$ was the result of the second batch of data (2003). PC1 accounted for $67.84 \%$ and PC2 accounted for $20.35 \%$ of the total variance. This figure represented the similar result of Fig. 3a. PC1 of Fig. 3c accounted for $63.33 \%$ and PC2 accounted for $23.09 \%$ of the total variance. Yangkou, Yantai, Yingkou, and Tianjin were divided into one group, which were relatively high contaminated by $\mathrm{HCHs}$ and others could be divided

Table 4

OCPs concentrations in mollusks in comparison with those of the reported concentrations

\begin{tabular}{|c|c|c|c|}
\hline Shellfish & Location & Compounds & Reference \\
\hline Mytilus edulis & $\begin{array}{l}\text { Perth (western } \\
\text { Australia) }\end{array}$ & $\begin{array}{l}\text { DDTs } 0.2 \mathrm{ng} \mathrm{g}^{-1} \\
\text { wet wt }\end{array}$ & $\begin{array}{l}\text { Sericano } \\
\text { et al. (1993) }\end{array}$ \\
\hline $\begin{array}{l}\text { Oyster } \\
\text { (Crassostrea } \\
\text { gigas) }\end{array}$ & $\begin{array}{l}\text { Taiwan } \\
\text { (China) }\end{array}$ & $\begin{array}{l}\text { HCHs } 0-7 \mathrm{ng} \mathrm{g}^{-1} \\
\text { dry wet } \\
\text { DDTs 0- } \\
121 \mathrm{ng} \mathrm{g}^{-1} \text { dry wet }\end{array}$ & $\begin{array}{l}\text { Ling and } \\
\text { Teng (1997) }\end{array}$ \\
\hline Mussel & $\begin{array}{l}\text { The marine } \\
\text { coastal (USA) }\end{array}$ & $\begin{array}{l}\text { DDTs } 0.51- \\
27.9 \mathrm{ng} \mathrm{g}^{-1} \text { dry wt }\end{array}$ & $\begin{array}{l}\text { O'Connor and } \\
\text { Beliaeff (1998) }\end{array}$ \\
\hline Mussel & $\begin{array}{l}\text { Coastal water } \\
\text { of Thailand }\end{array}$ & $\begin{array}{l}\text { DDTs } 0.05- \\
5.7 \mathrm{ng} \mathrm{g}^{-1} \text { wet wt } \\
\text { Chlordane } 0.22- \\
12.0 \mathrm{ng} \mathrm{g}^{-1} \text { wet wt }\end{array}$ & $\begin{array}{l}\text { Boonyatumanond } \\
\text { et al. (2002) }\end{array}$ \\
\hline $\begin{array}{l}\text { Mediterranean } \\
\text { mussel }\end{array}$ & Adriatic Sea & $\begin{array}{l}\text { DDTs } 159.24- \\
209.68 \mathrm{ng} \mathrm{g}^{-1} \\
\text { fat weight }\end{array}$ & $\begin{array}{l}\text { Perugini } \\
\text { et al. (2004) }\end{array}$ \\
\hline
\end{tabular}


into another group. The results of 2004 were a little difference against to 2002 and 2003. But on the whole, the pollution of $\mathrm{HCHs}$ were not so serious in these sampling sites, the polluted character of $\mathrm{HCHs}$ were not significant change in the three years.

(a) $2002 \mathrm{HCHs}$ a: $\alpha-\mathrm{HCH} ;$ b: $\beta-\mathrm{HCH} ; \mathrm{c}: \gamma-\mathrm{HCH} ; \mathrm{d}: \delta-\mathrm{HCH}$

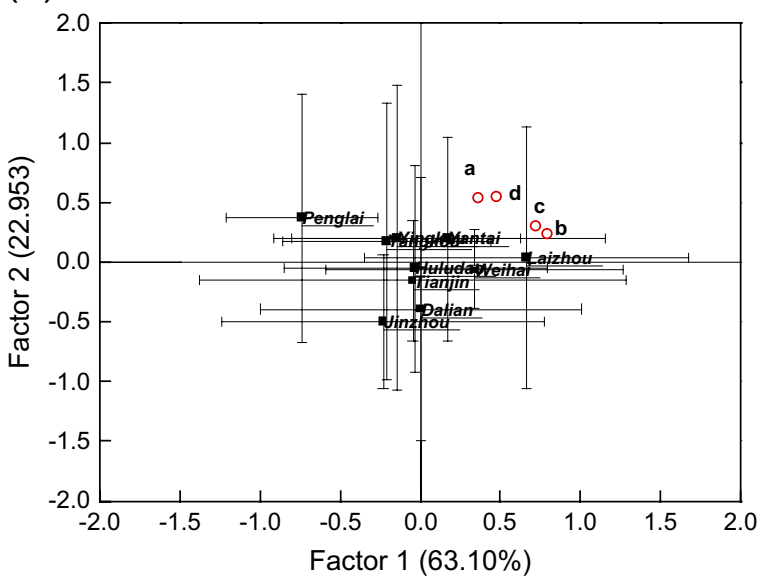

(b) $2003 \mathrm{HCHs}$ a: $\alpha-\mathrm{HCH}$; b: $\beta-\mathrm{HCH} ; \mathrm{c}: \gamma-\mathrm{HCH} ; \mathrm{d}: \delta-\mathrm{HCH}$

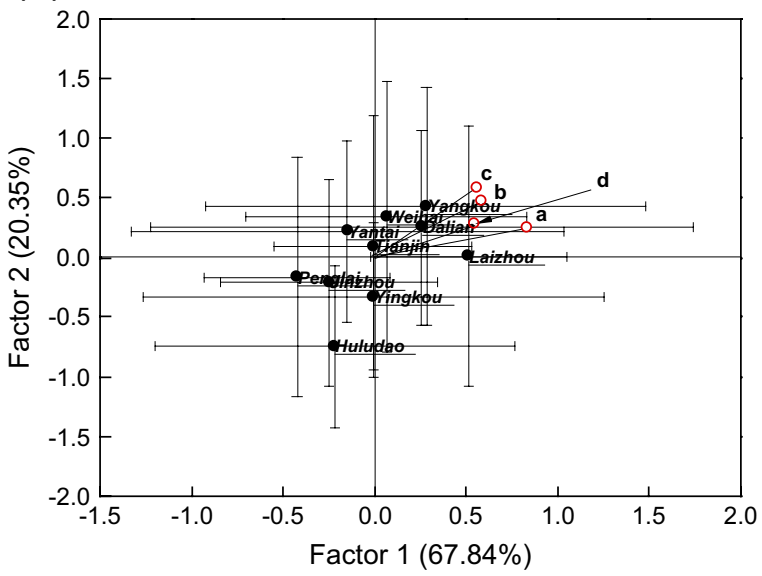

(c) $2004 \mathrm{HCHs}$ a: $\alpha-\mathrm{HCH}$; b: $\beta-\mathrm{HCH} ; \mathrm{c}: \gamma-\mathrm{HCH}$; : $\delta-\mathrm{HCH}$

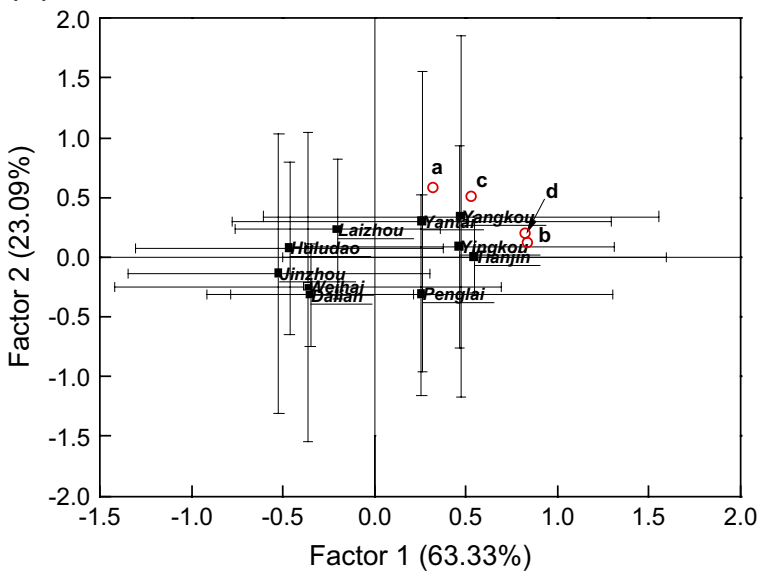

Fig. 3. Biplot of principal component (PC) analysis (loading plots and score plots) with Varimax method. a: plot by using the data matrix of $\mathrm{\Sigma} H \mathrm{HHs}$ in mollusks collected in 2002; b: plot by using the data matrix of $\Sigma \mathrm{HCHs}$ in mollusks collected in 2003. c: plot by using the data matrix of $\Sigma \mathrm{HCH}$ in mollusks collected in 2004. "ם": sample sites; " $\bigcirc$ ": HCHs compounds.

\subsubsection{The results of $D D T$ s}

Fig. $4 \mathrm{a}-\mathrm{c}$ was the results of PCA using the three batch of residual of DDTs. It could be seen that Tianjin and Weihai were the most serious polluted sites by DDTs in the selected
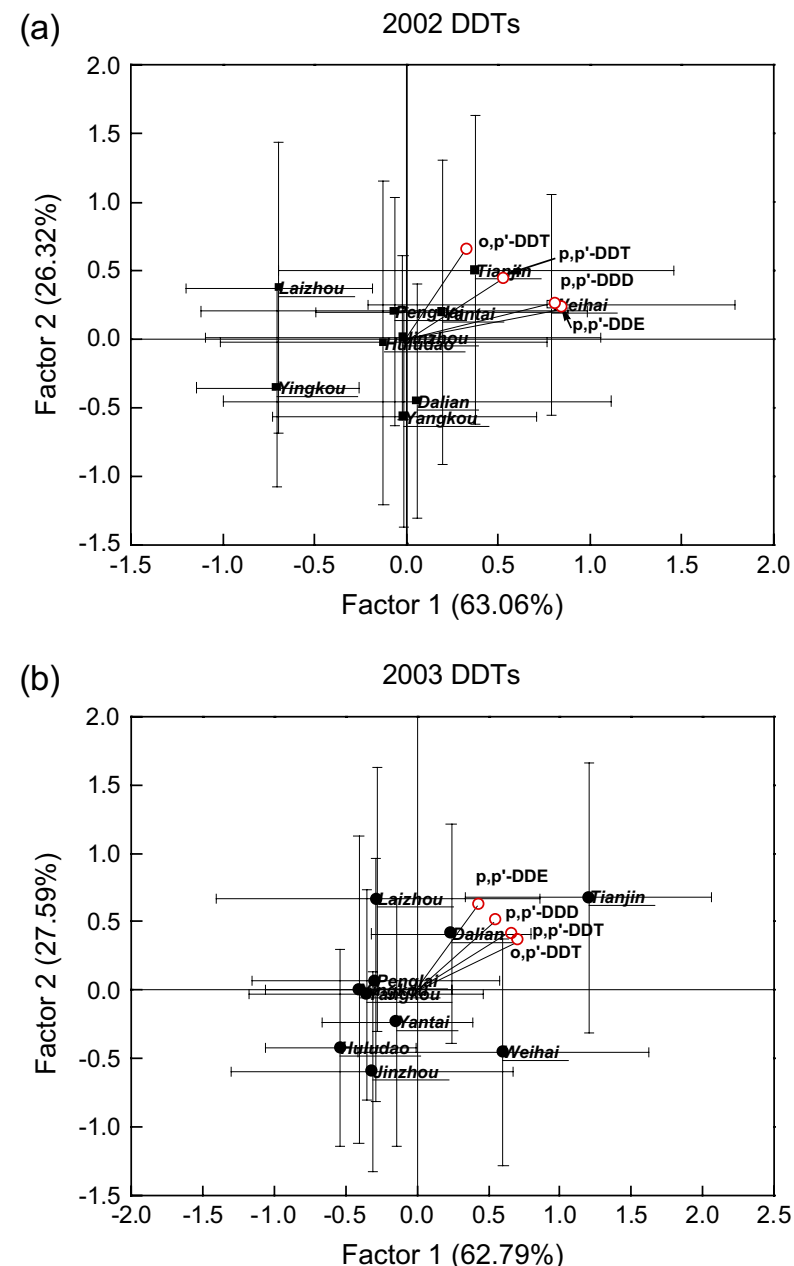

(c) 2004 DDTs

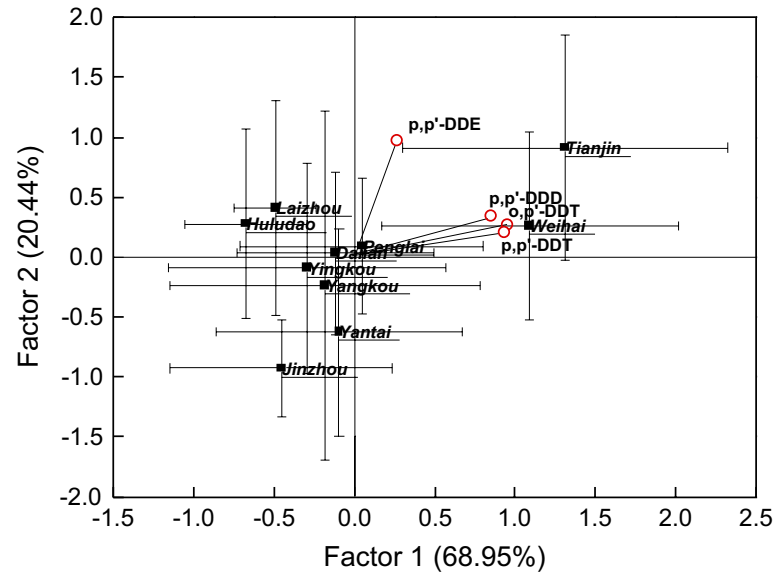

Fig. 4. Biplot of principal component (PC) analysis (loading plots and score plots) with Varimax method. a: plot by using the data matrix of $\Sigma$ DDTs in mollusks collected in 2002; b: plot by using the data matrix of $\Sigma$ DDTs in mollusks collected in 2003. c: plot by using the data matrix of $\Sigma$ DDTs in mollusks

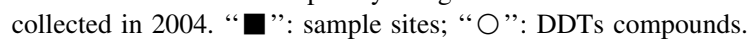


sampling area although the polluted characters were different in the several years. Thereinto, in 2002, the main residual in mollusks in Tianjin were $o, p^{\prime}$-DDT and $p, p^{\prime}$-DDT, while in 2003 and 2004, the polluted levels of the four kind of DDTs were comparable. In Weihai, the main residual OCPs in mollusks were $p, p^{\prime}$-DDD and $p, p^{\prime}$-DDE in 2002, $p, p^{\prime}$-DDT and $o, p^{\prime}$-DDT in 2003, $p, p^{\prime}$-DDT, $o, p^{\prime}$-DDT, and $p, p^{\prime}$-DDD in 2004, respectively.

\subsection{Composition analysis}

By analyzing the relative percentile of isomers of OCPs, much important information, such as source analysis, the mechanism of bioaccumulation and metabolism of organisms, can be obtained (Zhulidov et al., 2002). Fig. 5a-c and $6 a-c$ were the percent stacked columns of residual of $\mathrm{HCHs}$ and DDTs in mollusks.

For $\mathrm{HCHs}$, generally, the commercial mixtures contain 60$70 \% \alpha, 5-12 \% \beta, 6-10 \% \gamma$, and 3-4\% $\delta$ (Kutz et al., 1991). While, Fig. 5 showed that $\beta$-HCH was the main component of

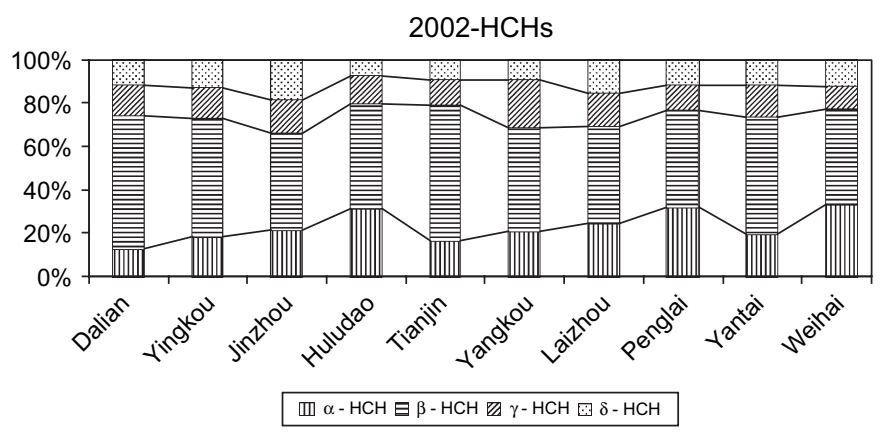

2003-HCHs
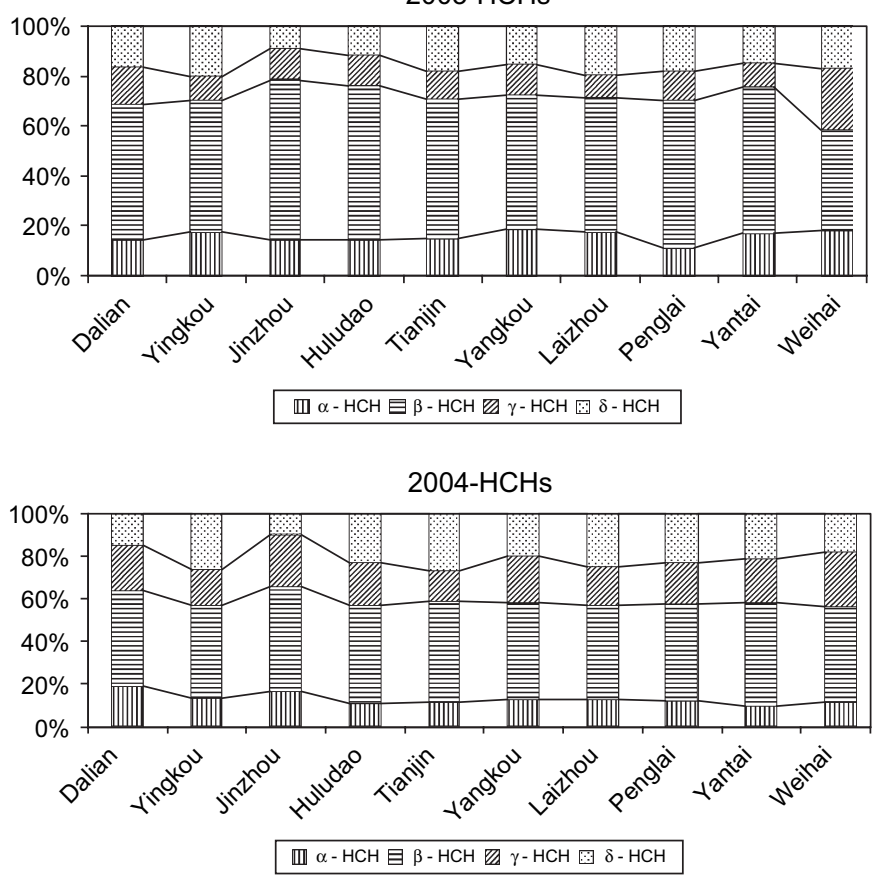

Fig. 5. The percent stacked columns of HCHs in mollusks collected in 2002, 2003, and 2004. the four isomers and in the period of three years, the ratio of the four isomers was not obviously changed. This is because $\beta$-HCH has relative lower vapor pressure and higher bio-enrichment factor and it is more stable in organism than other isomers. Other isomers can also be changed to $\beta-\mathrm{HCH}$ for a certain time. The greatest physical and metabolic stability to this isomer reflected the environmental and biological persistence (Willett et al., 1998). The results also indicated that there was no new source of HCHs in this period.

The percent composition of DDTs is about $75 \% p, p^{\prime}$-DDT, $15 \% o, p^{\prime}$-DDT, $5 \% p, p^{\prime}$-DDE, and others. In environmental condition, DDTs can be decomposed to DDE and DDD. The relatively higher percent of $p, p^{\prime}$-DDT indicated that there should be new DDTs source to be discharged into environment (Hites and Day, 1992). Fig. 6a-c represented the percent composition of residual of DDTs in selected mollusks. The percent of $p, p^{\prime}$-DDT in mollusks sampled in 2003 and 2004 are higher than that in 2002, which showed DDTs were still used in some area although the governments have banned to use DDTs in 1983. Some other study also showed there was new polluting source of DDTs in some areas (Klumpp et al., 2002; Mai et al., 2002; Wu et al., 1999).
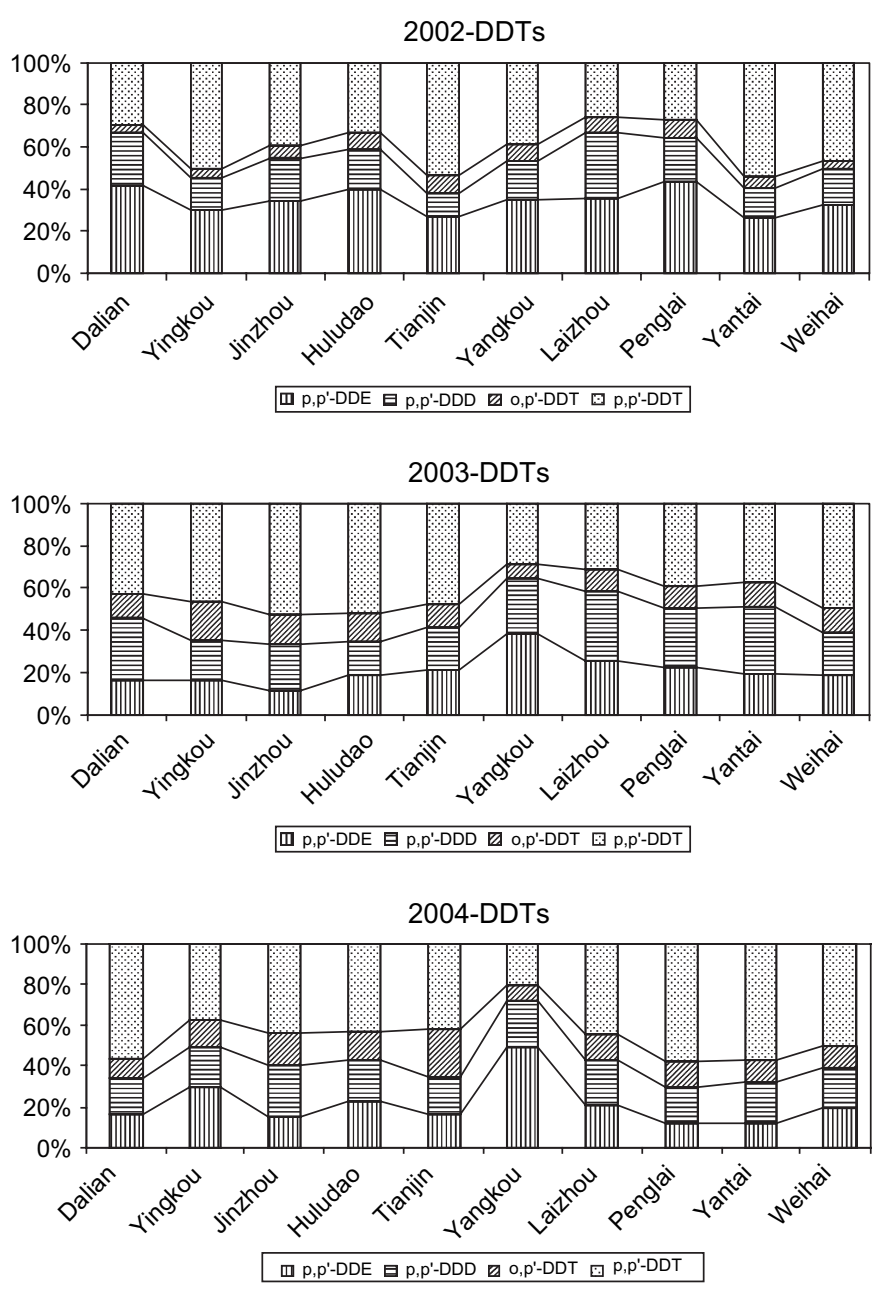

Fig. 6. The percent stacked columns of DDTs in mollusks collected in 2002, 2003, and 2004. 


\section{Conclusion}

This work investigated the residue of levels of OCPs in mollusks collected from coastal cities along the Chinese Bohai Sea. The results suggested OCPs existed widely in this area. Comparing to the data obtained from 2002 to 2004, there are no significant change of the concentrations of OCPs in the mollusks. In comparison with other area in the world, the levels in mollusks from Bohai Sea are at low levels.

\section{Acknowledgements}

This work was jointly supported by National Basic Research Program of China and Natural Science Foundation of China (2003CB415001, 20137010).

\section{References}

Bervotes, L., Voets, J., Cobaci, A., Chu, S.G., Qadah, D., Smolders, R., Schepens, P., Blust, R., 2005. Using of transplanted Zebra mussels (Dreissena polymorpha) to assess the bioavailability of microcontanminants in Flemish surface waters. Environmental Science \& Technology 39, 1492-1505.

Boonyatumanond, R., Jaksakul, A., Puncharoen, P., Tabucanon, M.S., 2002. Monitoring of organochlorine pesticides residues in green mussels (Perna viridis) from the coastal area of Thailand. Environmental Pollution 119, 245-252.

Chen, J.S., Gao, J.Q., 1993. The Chinese total diet study in 1990. Part I. Chemical contaminates. Journal of Association Official Analytical Chemistry 76, $1193-1205$.

Cleemann, M., Riget, F., Paulsen, G.B., de Boer, J., Dietz, R., 2000. Organochlorines in Greenland ringed seals (Phoca hispida). The Science of the Total Environment 245, 103-116.

Doong, R.A., Peng, C.K., Sun, Y.C., Liao, P.L., 2002. Composition and distribution of organochlorine pesticide residues in surface sediments from the Wu-shi river estuary, Taiwan. Marine Pollution Bulletin 45, 246-253.

Hites, R.K., Day, H.R., 1992. Unusual persistence of DDTs in some western USA soils. Bulletin of Environmental Contamination and Toxicology 48, 259-264.

Hobbs, K.E., Muir, D.C.G., Born, E.W., Dietz, R., Haug, T., Metcalfe, T., Metcalfe, C., Øien, N., 2003. Levels and patterns of persistent organochlorines in minke whale (Balaenoptera acutorostrata) stocks from the North Atlantic and European Arctic. Environmental Pollution 121, 239-252.

Hua, X.M., San, Z.J., 1996. The production and application of pesticides and factor analysis of their pollution in environment in China. Advance of Environmental Science (in Chinese) 4, 33-45.

Jacobs, M.N., Covaci, A., Gheorghe, A., Schepen, P., 2004. Time trend investigation of PCBs, PBDEs, and organochlorine pesticides in selected n-3 polyunsaturated fatty acid rich dietary fish oil and vegetable oil supplements; nutritional relevance for human essential n-3 fatty acid requirements. Journal of Agricultural and Food Chemistry 52, 1780-1788.

Jones, K.C., de Voogt, P., 1999. Persistent organic pollutants (POPs): state of the science. Environmental Pollution 100, 209-221.

Kim, S.K., Oh, J.R., Shim, W.J., Lee, D.H., Yim, U.H., Hong, S.H., Shin, Y.B., Lee, D.S., 2002. Geographical distribution and accumulation features of organochlorine residues in bivalves from coastal areas of South Korea. Marine Pollution Bulletin 45, 268-279.

Klumpp, D.W., Hong, H., Humphrey, C., Wang, X., Codi, S., 2002. Toxic contaminants and their biological effects in coastal waters of Xiamen, China.
Organic pollutants in mussels and fish tissues. Marine Pollution Bulletin 44, 752-760.

Kutz, F.W., Wood, P.H., Bottimore, D.P., 1991. Organochlorine pesticides and polychlorinated biphenyls in human adipose tissue. Reviews of Environmental Contamination and Toxicology 120, 1-82.

Li, Y.F., Cai, D.J., Shan, Z.J., 1998. Technical hexachlorocyclohexane use trends in China and their impact on the environment. Archives of Environmental Contamination and Toxicology 35, 688-697.

Ling, Y.C., Teng, H.C., 1997. Supercritical fluid extraction and cleanup of organochlorine pesticides and polychlorinated biphenyls in mussel. Journal of Chromatography A 790, 153-160.

Mai, B.X., Fu, J.M., Sheng, G.Y., Kang, Y.H., Lin, Z., Zhang, G., Min, Y.S., Zeng, E.Y., 2002. Chlorinated and polycyclic aromatic hydrocarbons in riverine and estuarine sediments from Pearl River delta, China. Environmental Pollution 117, 457-474.

Manz, M., Wenzel, K.D., Dietze, U., Schüürmann, G., 2001. Persistent organic pollutants in agricultural soils of central Germany. The Science of the Total Environment 277, 187-198.

Nakata, H., Kawazoe, M., Arizono, K., Abe, S., Kitano, T., Shimada, H., Li, W., Ding, X., 2002. Organochlorine pesticides and polychlorinated biphenyls residues in foodstuffs and human tissues from China: status of concentration, historical trends, and human dietary exposure. Archives of Environmental Contamination and Toxicology 43, 473-480.

O'Connor, T.P., Beliaeff B., 1998. Recent Trends in Coastal Environmental Quality (Result from the Mussel Watch Project, NOAA Silver Spring, MD, 40).

Perugini, M., Cavaliere, M., Giammarino, A., Mazzone, P., Olivieri, V., Amorena, M., 2004. Levels of polychlorinated biphenyls and organochlorine pesticides in some edible marine organisms from the Central Adriatic Sea. Chemosphere 57, 391-400.

Qi, Z.Y., Ma, X.T., Wang, Z.R., 1989. Molluska of Huanghai and Bohai. Agriculture Publishing House, Beijing, China.

Sericano, J.L., Wade, T.L., Brooks, J.M., Elliot, L.A., Fay, R.R., Wilkinson, D.L., 1993. National status and trends and mussel watch program: chlordane-related compounds in gulf of Mexico oysters. Environmental Pollution 82, 23-32.

Tanabe, S., Prudente, M.S., Kan-atireklap, S., Subramanian, A., 2000. Mussels watch: marine pollution monitoring of butyltins and organochlorines in coastal waters of Thailand, Philippines and India. Ocean Coastal Management 43, 819-839.

Vallack, H.W., Bakker, D.J., Brandt, I., Brorström-Lundén, E., Brouwer, A., Bull, K.R., Gough, C., Guardans, R., Holoubek, I., Jansson, B., Koch, R., Kuylenstierna, J., Lecloux, A., Mackay, D., McCutcheon, P., Mocarelli, P., Taalman, R.D.F., 1998. Controlling persistent organic pollutants - what next? Environmental Toxicology and Pharmacology 6, 143-175.

Wei, H., Tian, T., Zhou, F., Zhao, L., 2002. Numerical study on the water exchange of the Bohai Sea: simulation of the half-life time by dispersion model. Journal of Ocean University of Qingdao 32, 519-525 (in Chinese).

Willett, K.L., Ulrich, E.M., Hites, R.A., 1998. Differential toxicity and environmental fates of hexachlorocyclohexane isomers. Environmental Science and Technology 32, 2197-2207.

Wu, Y., Zhang, J., Zhou, Q., 1999. Persistent organochlorine residues in sediments from Chinese river/estuary systems. Environmental Pollution 105, $143-150$.

Xu, D.D., Zhong, W.K., Deng, L.L., Chai, Z.F., 2004. Regional distribution of organochlorinated pesticides in pine needles and its indication for socioeconomic development. Chemosphere 54, 743-752.

Yang, R.Q., Yao, Z.W., Jiang, G.B., Zhou, Q.F., Liu, J.Y., 2004. HCH and DDT residues in molluscs from Chinese Bohai coastal sites. Marine Pollution Bulletin 48, 795-805.

Zhulidov, A.V., Robarts, R.D., Headley, J.V., Liber, K., Zhulidov, D.A., Zhulidov, O.V., Pavlov, D.F., 2002. Levels of DDT and hexachlorocyclohexane in burbot (Lota lota L.) from Russian Arctic rivers. The Science of the Total Environment 292, 231-246. 